\title{
On Study
}

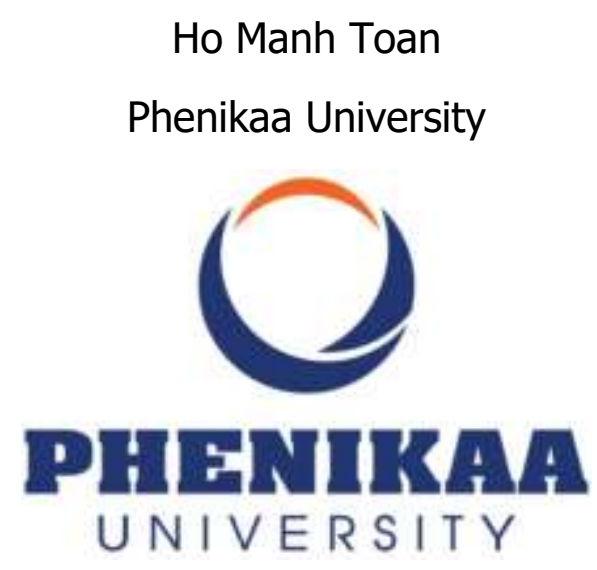

Originally Published: 17 November 2016

(Revised: 25 May 2021)

Recently, I had a conversation with my friend about our plans after graduation. She said she wants to go to work after graduation, partly because of the experiences it will bring and partly because she wants to be in a different environment, which is not about studying.

It is rather odd when it occurs to me that studying is the part she wants to avoid. I think learning and studying are fundamental to the development of human beings, regardless of environments or social, cultural backgrounds. Children used to learn different skills by closely engaging with works that contained such skills [1]. However, since the establishment of compulsory and mass schools, people's perception about studying and learning has been closely associated with the school.

By considering school as the sole method of studying, we not only have a misconception about studying but also take studying for granted. While you are schooling, the end of a school day means studying ends, the finishing of your homework means no more studying. It is destructive to realize that such a thought is deeply being mindsponged into students [2,3]. I believe most of us will lose the curiosity in studying and learning, or we will forget the thrill of getting to know something new because we have learned to time our study in specific hours and specific destinations. Thus, there is no more study once you are out of it. 
In reality, studying should be a never-ending process because knowledge is constantly being updated. "Wisest is she who knows she does not know." The world is constantly changing, and there is no way, by no means, a person can possibly put all of that knowledge into his pocket. Thus, the wisest might not be the one who knows all the knowledge, but the one who knows less and less about more and more until he knows nothing about everything. Eventually, the remain constant is a proactive attitude toward learning [4]. Indeed, this is a complex philosophical thought, but I guess it can be applied to all.

My dad stopped school after secondary, and only in his 40s did he finally achieve his high school degree by spending a night studying Mathematics, Physics, and Chemistry with my brother. His knowledge in History, Geography, and Literature has been built up throughout his life. John Taylor Gatto (2005) said that reading, writing, and arithmetic would take a person only a hundred hours to achieve [1]. Thus, why we need five years of elementary for the basic and then seven years of high school to go not much further?

Five years later: 5 years ago, I started to ask why and then questioned the role of the school. I have my answer now. The school is a place to help children practicing social skills in a safe environment. As much as we hated it while we were there, the school is still a safe method of transmitting knowledge to the next generations. Deschooling $[1,5]$ is about abolishing our school. Perhaps, it means reforming the school in a radical and critical manner to ensure the cost of the society [6] and the integrity of our children [7].

\section{References}

[1] Gatto, J.T. (2005). Dumbing us down the hidden curriculum of compulsory schooling. New Society Publishers.

[2] Vuong, Q. H., \& Napier, N. K. (2015). Acculturation and global mindsponge: an emerging market perspective. International Journal of Intercultural Relations, 49, 354-367.

[3] Vuong, Q. H. (2016). Global mindset as the integration of emerging socio-cultural values through mindsponge processes: A transition economy perspective. In J. Kuada (ed.) Global Mindsets: Exploration and Perspectives (pp. 109-126). London: Routledge.

[4] Vuong, Q. H. (2019). Breaking barriers in publishing demands a proactive attitude. Nature Human Behaviour, 3(10), 1034, DOI: 10.1038/s41562-019-0667-6.

[5] Illich, I., (1971). Deschooling society. Marion Boyars Publishers 
[6] Vuong, Q. H. (2018). The (ir)rational consideration of the cost of science in transition economies. Nature Human Behaviour, 2(1), 5, DOI: 10.1038/s41562017-0281-4.

[7] Vuong, Q. H. (2020). Reform retractions to make them more transparent. Nature, 582(7811), 149, DOI:10.1038/d41586-020-01694-x 